www.jmscr.igmpublication.org

Impact Factor 5.84

Index Copernicus Value: 71.58

ISSN (e)-2347-176x ISSN (p) 2455-0450

crossref DOI: _https://dx.doi.org/10.18535/jmscr/v5i11.112

Journal Of Medical Science And Clinical Research

\title{
Prevalence of Body Dysmorphic Disorder in Patients Attending Dermatology clinic in Saudi Arabia/Qassim Region
}

\author{
Authors \\ Huda Ghadir Alonazi (PI), Dr Mansour Alharbi, Lina Abdul Mohsen Alyousif, \\ Wafa Alialaswad, Jawaher Mohammad Alharbi, Muna Ahmad Almalki, \\ Bashayer Frhan Alrashedee
}

\begin{abstract}
Objective: To assess the prevalence of Body Dysmorphic Disorder in Patients attending a dermatology clinic in Saudi Arabial Qassim Region.

Methods: Cross sectional study conducted among 363 patients aged 15 years old and more. Patients responded to an Arabic electronic questionnaire that was developed as a screening instrument for BDD in psychiatric settings and was validated in a psychiatric outpatient sample. The BDDQ is intended as a screening instrument and not as a diagnostic one. Data were analyzed by SPSS program version 22.

Results: The sample was consisted of 91,1\% women and 8,9\% men. Our survey shows that 18, 6\% of patients are likely to undergo Body Dysmorphic Disorder. The proportion of patients with possible BDD was showed significantly decreased with age $(p=0,001)$, however, it was significantly highly expressed in married patients and students (respectively $p=0,009, p=0,007$ ) when using Chi-squared test.

Conclusion: Body Dysmorphic Disorder in patients attending the dermatology clinic is relatively common. Dermatologists should master the measures to identify this health problem in their patients and refer them to mental health specialists.
\end{abstract}

\section{Introduction}

Body dysmorphic disorder (BDD), also known as dysmorphophobia, is a common and severe psychiatric disorder that occurs around the world affects $1.7 \%$ to $2.4 \%$ of the general population. ${ }^{(1)}$ Patients with BDD believe they look ugly or deformed (thinking, for example, that they have a severely scarred skin), when in reality they look normal. Concerns most often focus on the face or head (e.g., acne or skin color, balding, or head size) but can include any body area or the entire body, and concern with multiple body areas is typical. The appearance preoccupations are diffic- ult to resist or control, and on average consume 3 to 8 hours a day ${ }^{(2)}$. They are often associated with fears of rejection and feelings of low self-esteem, shame, embarrassment, unworthiness, and being unlovable and insight is usually poor.

A majority has ideas or delusions of reference, thinking that others take special notice of the 'defect', perhaps staring at it, talking about it, or mocking it. Most patients perform repetitive compulsive behaviors aimed at examining, improving, or hiding the 'defect'. Common behaviors include mirror checking, comparing with others, excessive grooming (e.g., applying 
makeup, hair styling), camouflaging (e.g., with a hat, clothes, or makeup), frequent clothes changing, reassurance seeking, skin picking, and eating a restricted diet.

Because this disorder is relatively common and patients reluctant to seek help because they feel ashamed or embarrassed and it causes markedly poor quality of life and significant distress and impairment in functioning as they may stop working and socializing, become housebound, and even commit suicide and Its usually misdiagnosed as most patients seek non psychiatric treatment (most commonly dermatologic and surgical) we made this research to estimate prevalence of BBD in Qassim region.

\section{Methods}

Our survey sample comprised 363 patients from Qassim Region (KSA) aged 15 years old and more. The study subjects were randomly selected through an electronic questionnaire that had been translated into Arabic and collected from patients in dermatology clinics from different Hospitals in $\mathrm{Al}$ Qassim region. The questionnaire consisted of two parts. The first part included sociodemographic data: age, nationality, city, gender, marital status, occupation and educational level and the second part included the Body Dysmorphic Disorder Questionnaire (BDDQ) which is a brief, self-report measure that is derived from the DSM-IV diagnostic criteria for BDD. Using close-ended questions, it asks the respondents whether their appearance concerns are sources of preoccupation and, if so, it assesses the degree to which they cause distress or interfere with the person's social or occupational functioning. The questionnaire was developed as a screening instrument for BDD in psychiatric settings and was validated in a psychiatric outpatient sample, displaying high sensitivity (100\%) and specificity (93\%) (4). The BDDQ is intended as a screening instrument and not as a diagnostic one. It suggests that BDD is present, but not necessarily surely diagnosed.
The Body Dysmorphic Disorder Questionnaire (BDDQ) is a 7-item short questionnaire (Table A). "Yes" answer to the questions 9 and 10 was required to continue the questionnaire."Yes" answer to at least one of the questions 11 to 14 and a spent time thinking in oneself defect $>=1$ hour for the $15^{\text {th }}$ question were needed for a possible BDD diagnosis. Each positive answer was rated 1. For the validation, the BDDQ was scored from 0 to 4 points (Table 1 ). The scoring from 0-4 was made in order to evaluate the questionnaire's capacity to distinguish BDD from non-BDD at increasing levels of appearance concern. We used a severity scale from 0 to 4 $(0=$ level $0,1=$ level 1, 2=level 2, 3= level 3, level 4). Patients grouped into the BDDQ score levels $0,1,2,3$ were considered as in negative BDDscreening group and BDDQ score of 4 was equal to the fulfillment of the BDD criteria and was thus considered a positive BDD-screening. To ensure a validation of the questionnaire's properties at the different levels of appearance concern, an interview sample was created that included respondents from all these BDDQ score levels.

Table A: Scoring of the Body Dysmorphic Disorder Questionnaire (BDDQ) ${ }^{\mathbf{1}}$

\begin{tabular}{|c|c|c|}
\hline BDDQ question & Answer $^{\mathrm{a}}$ & $\begin{array}{l}\text { BDDQ } \\
\text { score }\end{array}$ \\
\hline $\begin{array}{l}\text { Q9. Are you very concerned about the } \\
\text { appearance of some part(s) of your body } \\
\text { that you consider especially unattractive? }\end{array}$ & Yes & 1 \\
\hline $\begin{array}{l}\text { Q10. Do these concerns preoccupy you? } \\
\text { That is, do you think about them a lot and } \\
\text { wish you could think about them less? }\end{array}$ & Yes & 2 \\
\hline Q11.Do other people remark your defect? & \multirow{4}{*}{$\begin{array}{l}\text { Yes to at } \\
\text { least one } \\
\text { question }\end{array}$} & \multirow[t]{4}{*}{3} \\
\hline $\begin{array}{l}\text { Q12.Has your defect(s) caused you a lot of } \\
\text { distress, torment or pain? }\end{array}$ & & \\
\hline $\begin{array}{l}\text { Q13.Has your defect(s) significantly } \\
\text { interfered with yoursocial life? }\end{array}$ & & \\
\hline $\begin{array}{l}\text { Q14.Has your defect(s) significantly } \\
\text { interfered with your school work, your job } \\
\text { or your ability to function in your role? }\end{array}$ & & \\
\hline $\begin{array}{l}\text { Q15.How much time do you spend thinking } \\
\text { about your defect(s) per day on average? }\end{array}$ & $\geq 1$ hour & 4 \\
\hline
\end{tabular}

SPSS program (version 22.0, SPSS Inc, Chicago, IL) was used for data statistical analysis. We used descriptive analysis to determine patient's socio-

\footnotetext{
${ }^{1}$ Adopted and modified from "Validation of the Body Dysmorphic Disorder Questionnaire in a community sample of Swedish women" by Sabina Brohede, Gun Wingren, Barbro Wijma and KlaasWijma.
} 
demographic characteristics and to evaluate the Prevalence of Body Dysmorphic Disorder in Patients with dermatological conditions. Alpha Cronbach test and Pearson correlation test were used to determine reliability and internal consistency of the questionnaire. The Chi-squared test was used to determine the significance of the relationship between socio-demographic factors and the Body Dysmorphic Disorder in dermatology patients. $\mathrm{P}=<0,05$ was considered as statistically significant. We included All women and men, above 15, saudi and non from Qassim Region, attending dermatology clinic . Exclusion criteria: below 15, not from Qassim Region.

\section{Results}

\section{A-Descriptive analysis}

\section{1-Demographics of the studied subjects}

Table 1: Socio-demographic characteristics of the studied patients $(\mathrm{n}=363)$

\begin{tabular}{|c|c|c|}
\hline & & n Percent \\
\hline \multirow[t]{5}{*}{ Age } & $15-25$ & $176(48,6 \%)$ \\
\hline & $26-35$ & $95(26,2 \%)$ \\
\hline & $36-45$ & $64(17,7 \%)$ \\
\hline & $>45$ & $27(7,5 \%)$ \\
\hline & Total & $362(100 \%)$ \\
\hline \multicolumn{3}{|c|}{ Nationality } \\
\hline & Saudi & $331(91,4 \%)$ \\
\hline & Non-SAudi & $31(8,6 \%)$ \\
\hline & Total & $362(100,0 \%)$ \\
\hline \multicolumn{3}{|l|}{ City } \\
\hline & Buraidah & $202(56,0 \%)$ \\
\hline & Unaizah & $12(3,3 \%)$ \\
\hline & Al Rass & $10(2,8 \%)$ \\
\hline & Al Bukairiyah & $6(1,7 \%)$ \\
\hline & Others & $131(36,3 \%)$ \\
\hline & Total & $361(100,0 \%)$ \\
\hline \multicolumn{3}{|c|}{ Gender } \\
\hline & Male & $32(8,9 \%)$ \\
\hline & Female & $326(91,1 \%)$ \\
\hline & Total & $358(100,0 \%)$ \\
\hline \multicolumn{3}{|c|}{ Marital Status } \\
\hline & Single & $167(46,1 \%)$ \\
\hline & Married & $191(52,8 \%)$ \\
\hline & Divorced & $4(1,1 \%)$ \\
\hline & Widowed & 0 \\
\hline & Total & $362(100,0 \%)$ \\
\hline \multicolumn{3}{|c|}{ Occupation } \\
\hline & Student & $161(44,6 \%)$ \\
\hline & Teacher & $66(18,3 \%)$ \\
\hline & Physician & $6(1,7 \%)$ \\
\hline & Others & $128(35,5 \%)$ \\
\hline & Total & $361(100,0 \%)$ \\
\hline \multicolumn{3}{|c|}{ Educational Level } \\
\hline & Elementary & $10(2,8 \%)$ \\
\hline & Intermediate & $17(4,7 \%)$ \\
\hline & Secondary & 72 \\
\hline & University & 260 \\
\hline & Unlettered & 3 \\
\hline & Total & 362 \\
\hline
\end{tabular}

Table 1 shows the socio-demographic characteristics of the study sample, subjects were 363 men $(8,9 \%)$ and women $(91,1 \%)$ (figure 4), aged in $48,6 \%$ of cases in the $15-25$ years range (figure 1). Almost allparticipants were Saudi $(91,4 \%)$ (figure 2) and most patients lived in Buraidah City (56\%) (figure 3). Nearly the half $(52,8 \%)$ were married (figure 5$)$. The majority of subjects were students $(44,6 \%)$ (figure 6) and had university degrees $(71,8 \%)$ (figure 7$)$.

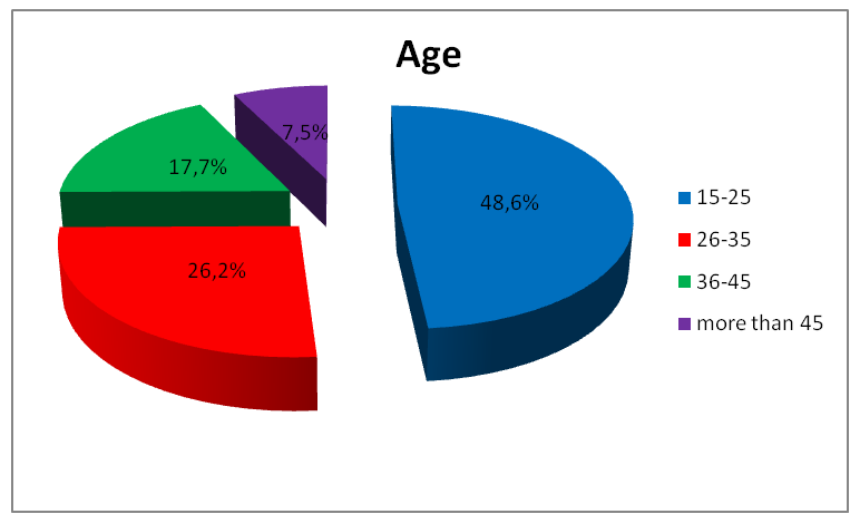

Figure 1: Age categories of the studied patients

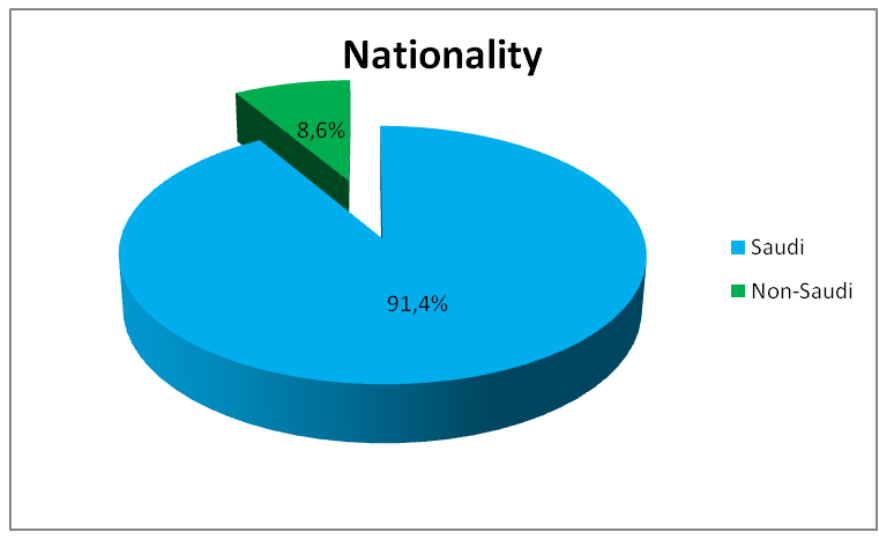

Figure 2: Nationalities of the studied patients

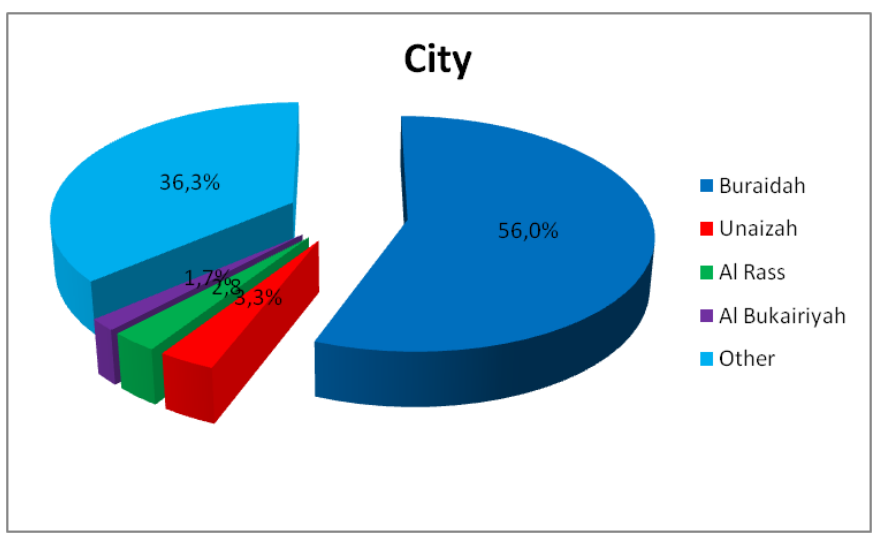

Figure 3: Residence city of the studied patients 


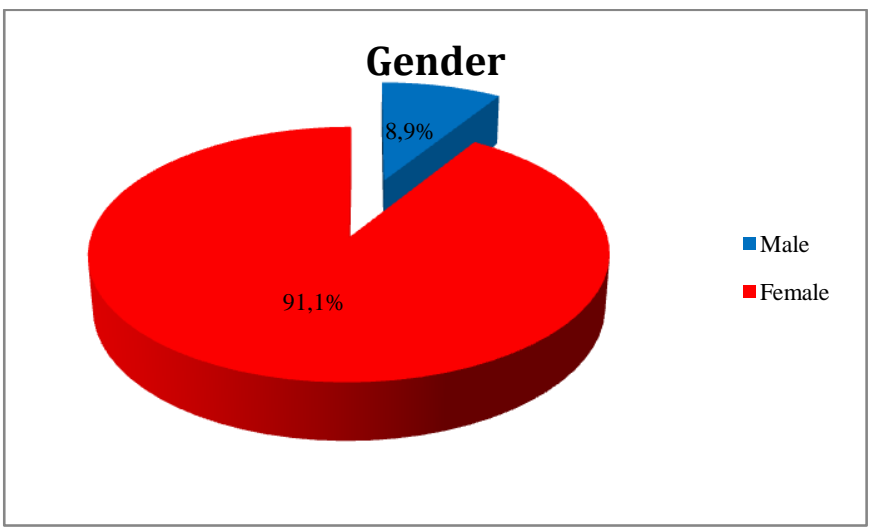

Figure 4: Gender of the studied patients

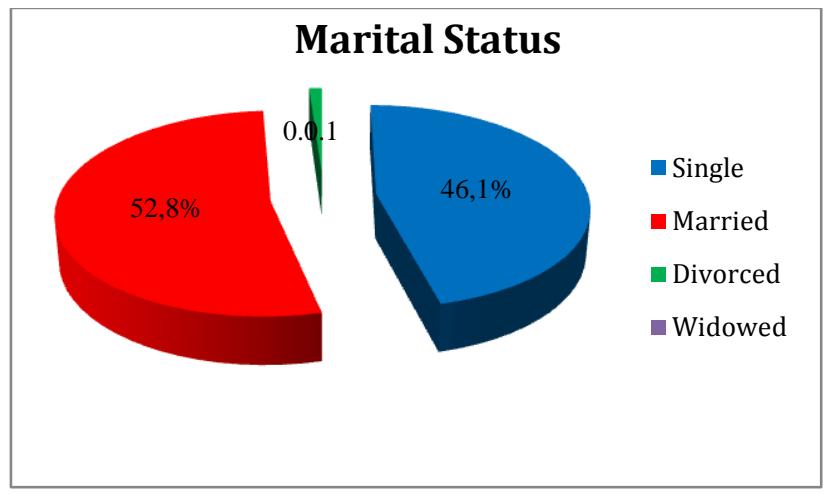

Figure 5: Marital status of the studied patients

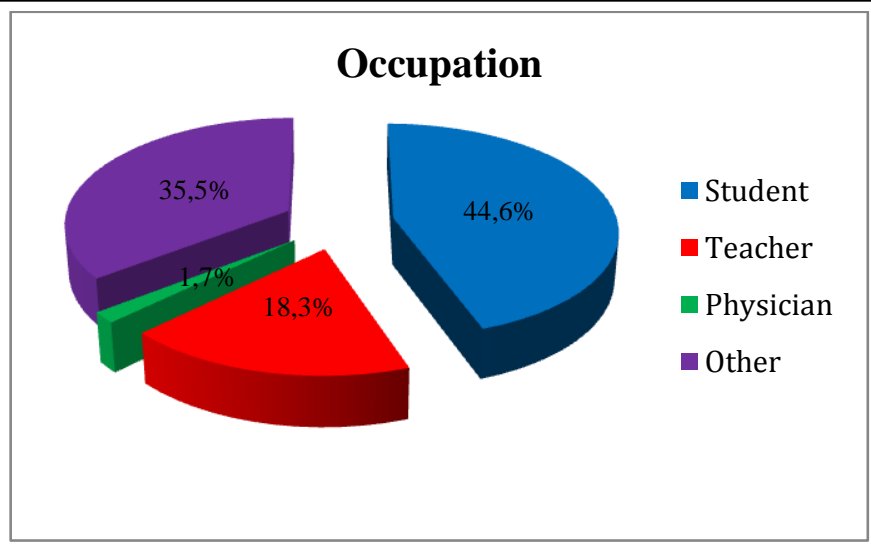

Figure 6: Occupation of the studied patients

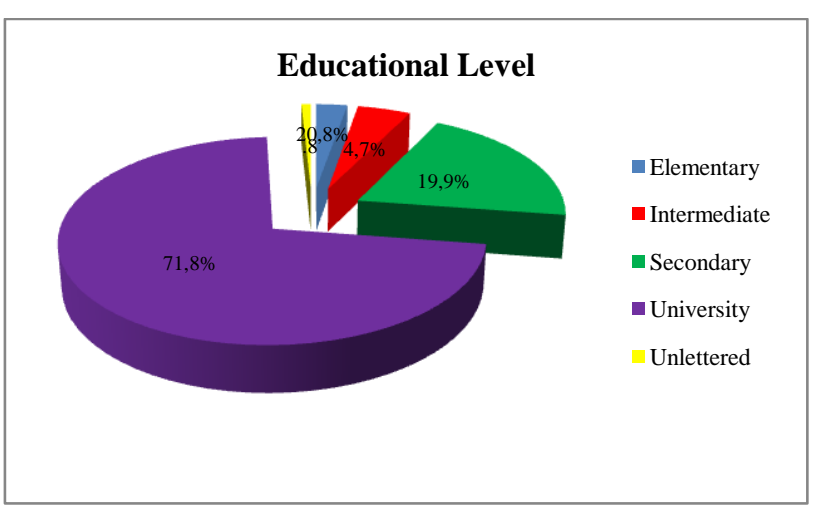

Figure 7: Educational level of the studied patients

\section{2-Reliability}

Reliability of the BDDQ was adequate since Cronbach's Alpha value=0,810.

\section{Reliability Statistics}

\begin{tabular}{|c|c|c|}
\hline Cronbach's Alpha & Cronbach's Alpha Based on Standardized Items & N of Items \\
\hline, 810 &, 815 & 7 \\
\hline
\end{tabular}

\section{Item-Total Statistics}

\begin{tabular}{|c|c|c|c|c|c|}
\hline & $\begin{array}{c}\text { Scale Mean if Item } \\
\text { Deleted }\end{array}$ & $\begin{array}{c}\text { Scale Variance if Item } \\
\text { Deleted }\end{array}$ & $\begin{array}{c}\text { Corrected Item-Total } \\
\text { Correlation }\end{array}$ & $\begin{array}{c}\text { Squared Multiple } \\
\text { Correlation }\end{array}$ & $\begin{array}{c}\text { Cronbach's Alpha if } \\
\text { Item Deleted }\end{array}$ \\
\hline $\begin{array}{c}\text { Are you very concerned about the } \\
\text { apperance of some }\end{array}$ & 5,82 & 28,003 &, 377 &, 256 &, 818 \\
$\begin{array}{c}\text { Do these concerns preoccupy you? That } \\
\text { is, do you }\end{array}$ & 5,47 & 23,442 &, 550 &, 428 &, 786 \\
$\begin{array}{c}\text { think about them a lot and wish you } \\
\text { could think about }\end{array}$ & 5,70 & 19,647 &, 653 &, 765 &, 761 \\
$\begin{array}{c}\text { Has your defect(s) caused you a lot of } \\
\text { distress, }\end{array}$ & 5,59 & 19,166 &, 672 &, 308 &, 793 \\
$\begin{array}{c}\text { Has your defect(s) significantly } \\
\text { interfered with your }\end{array}$ & 6,28 & 23,871 &, 502 &, 398 &, 778 \\
$\begin{array}{c}\text { Has your defect(s) significantly } \\
\text { interfered with your }\end{array}$ & 6,16 & 22,317 &, 586 &, 352 &, 781 \\
$\begin{array}{c}\text { How much time do you spend thinking } \\
\text { about your }\end{array}$ & 4,85 & 20,925 & & & \\
\hline
\end{tabular}

The obtained Pearson correlation coefficients are acceptable and statistically significant, which indicates that the questionnaire has an acceptable internal consistency. 


\section{Correlations}

\begin{tabular}{|c|c|c|c|c|c|c|c|c|}
\hline & & Q9 & Q10 & Q11 & Q12 & Q13 & Q14 & Q15 \\
\hline \multirow[t]{3}{*}{ Q9 } & Pearson Correlation & 1 &, $503^{* *}$ &, $315^{* *}$ &, $331^{*}$ &, $143^{* *}$ & $218^{*}$ & $220^{* * 2}$ \\
\hline & Sig. (2-tailed) & & 000 & ,000 & 000 &, 008 &, 000 & ,000 \\
\hline & $\mathrm{N}$ & 361 & 334 & 344 & 343 & 345 & 344 & 351 \\
\hline \multirow[t]{3}{*}{$\overline{\mathrm{Q} 10}$} & Pearson Correlation &, $503^{* *}$ & 1 &, $475^{* 27}$ &, $503^{*}$ & $225^{* 3}$ &, $304^{37}$ &, $404^{* * 1}$ \\
\hline & Sig. (2-tailed) & ,000 & & ,000 & 000 & ,000 & ,000 & ,000 \\
\hline & $\mathrm{N}$ & 334 & 334 & 334 & 332 & 334 & 333 & 331 \\
\hline \multirow[t]{3}{*}{$\mathrm{Q} 11$} & Pearson Correlation & $315^{* *}$ &, $475^{* 21}$ & 1 &, $593^{*}$ &, $406^{*}$ &, $424^{*}$ & $459^{* x}$ \\
\hline & Sig. (2-tailed) & ,000 & ,000 & &, 000 &, 000 & ,000 & ,000 \\
\hline & $\mathrm{N}$ & 344 & 334 & 344 & 342 & 344 & 343 & 341 \\
\hline \multirow[t]{3}{*}{$\mathrm{Q} 12$} & Pearson Correlation & $331^{* *}$ &, $503^{* * 1}$ &, $593^{* *}$ & 1 &, $412^{*}$ &, $482^{* *}$ & $438^{* * 2}$ \\
\hline & Sig. (2-tailed) & ,000 & ,000 & ,000 & &, 000 &, 000 & ,000 \\
\hline & $\mathrm{N}$ & 343 & 332 & 342 & 343 & 343 & 342 & 339 \\
\hline \multirow[t]{3}{*}{$\mathrm{Q} 13$} & Pearson Correlation &, $143^{* *}$ & $225^{* * 1}$ &, $406^{* *}$ &, $412^{*}$ & 1 &, $489^{* *}$ &, $338^{* *}$ \\
\hline & Sig. (2-tailed) & ,008 & ,000 & ,000 &, 000 & & 000 & ,000 \\
\hline & $\mathrm{N}$ & 345 & 334 & 344 & 343 & 345 & 344 & 341 \\
\hline \multirow[t]{3}{*}{$\mathrm{Q} 14$} & Pearson Correlation & $218^{* *}$ &, $304^{3 *}$ &, $424^{* * \pi}$ &, $482^{*}$ &, $489^{*}$ & 1 &, $487^{*}$ \\
\hline & Sig. (2-tailed) & ,000 & 000 & ,000 &, 000 & 000 & & ,000 \\
\hline & $\mathrm{N}$ & 344 & 333 & 343 & 342 & 344 & 344 & 340 \\
\hline \multirow[t]{3}{*}{$\mathrm{Q} 15$} & Pearson Correlation & $220^{* *}$ & $404^{*}$ & $459^{* *}$ &, $438^{*}$ &, $338^{*}$ &, $487^{*}$ & 1 \\
\hline & Sig. (2-tailed) & ,000 & 000 &, 000 & ,000 &, 000 &, 000 & \\
\hline & $\mathrm{N}$ & 351 & 331 & 341 & 339 & 341 & 340 & 351 \\
\hline
\end{tabular}

**. Correlation is significant at the 0.01 level (2-tailed).

\section{3-BDDQ score}

Table 2 shows that positive BDD-screening patients $(\mathrm{n}=67)$ presented $18,6 \%$, compared to $81,4 \% \quad(n=294)$ of participants who were Negative BDD-screening ones (level 0 (23,3\%), level $1(23,5 \%)$, level $2(13,3 \%)$ and level 3

Table 2: Prevalence of Body Dysmorphic Disorder in studied patients

\begin{tabular}{|c|c|c|}
\hline BDDQ score & Frequency & Percent (\%) \\
\hline Negative BDD-screening & 294 & 81,4 \\
Positive BDD-screening & 67 & 18,6 \\
Total & 361 & 100,0 \\
\hline
\end{tabular}
$(21,3 \%)$ ) (figure 8 ).

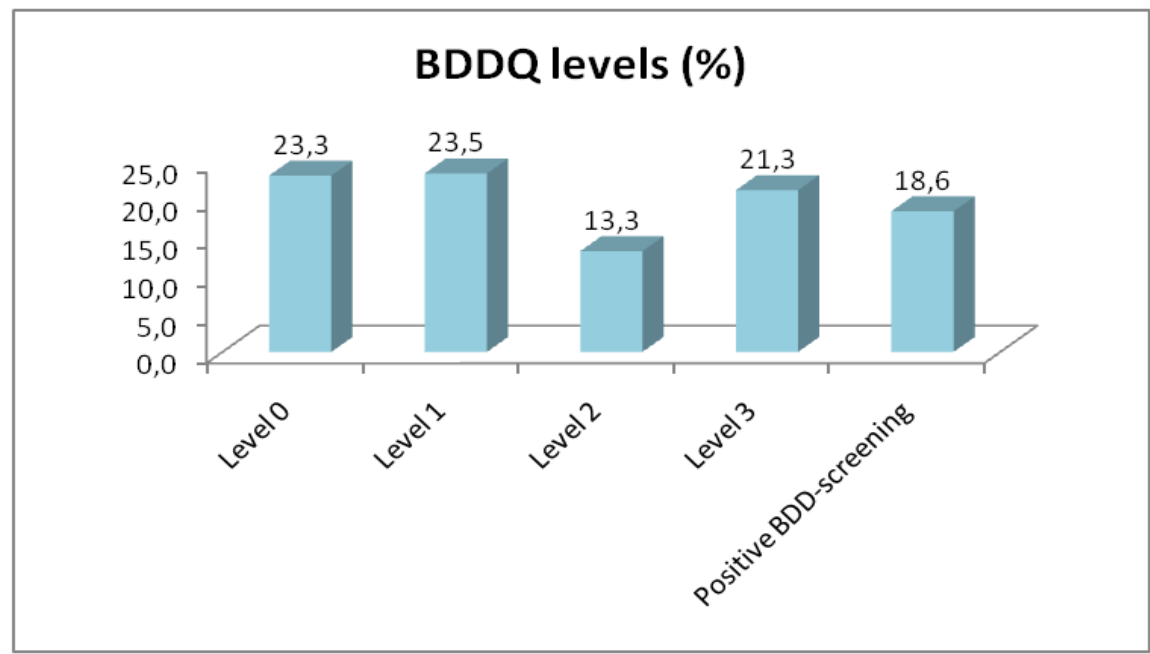

Figure 8: BDDQ levels in the studied subjects

\section{B-Relation with socio-demographic factors}

The proportion of patients who are likely to develop BDD significantly decrease with age $(p=0,001)$. Married subjects and students have significantly higher possibility to develop BDD (respectively $\mathrm{p}=0,009, \mathrm{p}=0,007$ ). 
*Prevalence of BDD in relation to age

Crosstab

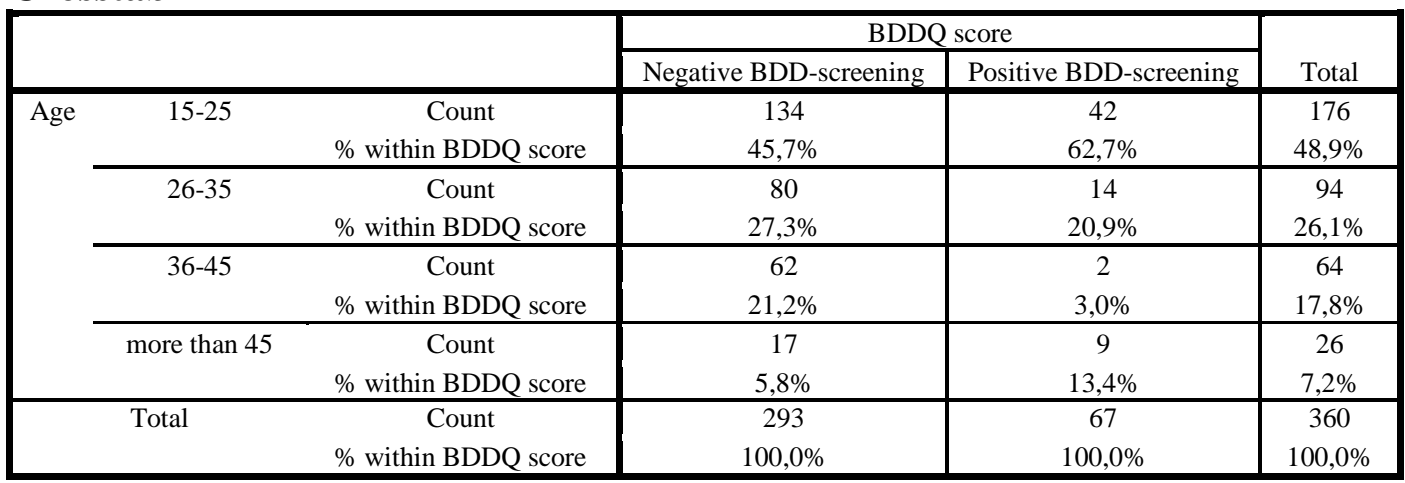

Chi-Square Tests

\begin{tabular}{|c|c|c|c|}
\hline & Value & df & Asymp. Sig. (2-sided) \\
\hline Pearson Chi-Square & $18,592^{\mathrm{a}}$ & 3 &, 001 \\
Likelihood Ratio & 22,097 & 3 &, 000 \\
Linear-by-Linear Association & 2,313 & 1 &, 128 \\
N of Valid Cases & 360 & & \\
\hline
\end{tabular}

a. 1 cells $(12,5 \%)$ have expected count less than 5 . The minimum expected count is 4,84 .

*Prevalence of BDD in relation to the nationality

Crosstab

\begin{tabular}{|ccc|c|c|c|}
\hline & & \multicolumn{2}{|c|}{ BDDQ score } & \multirow{2}{*}{ Total } \\
\cline { 3 - 6 } & & Negative BDD-screening & Positive BDD-screening & Count \\
\multirow{2}{*}{ Nationality } & Saudi & 268 & 62 & 330 \\
& & \% within BDDQ score & $91,2 \%$ & $92,5 \%$ & $91,4 \%$ \\
\cline { 2 - 5 } & \multirow{2}{*}{ Non-Saudi } & Count & 26 & 5 & 31 \\
& \% within BDDQ score & $8,8 \%$ & $7,5 \%$ & $8,6 \%$ \\
\hline \multirow{2}{*}{ Total } & Count & 294 & 67 & 361 \\
& \% within BDDQ score & $100,0 \%$ & $100,0 \%$ & $100,0 \%$ \\
\hline
\end{tabular}

*Prevalence of BDD in relation to the city

Crosstab

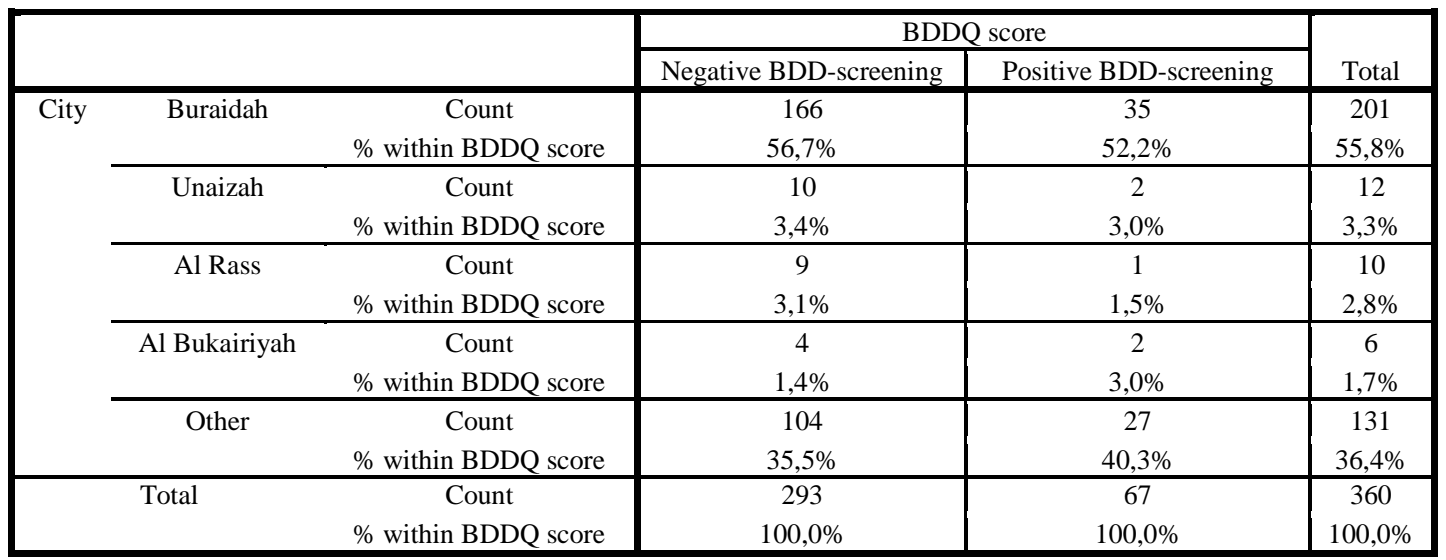

Chi-Square Tests

\begin{tabular}{|c|c|c|c|}
\hline & Value & df & Asymp. Sig. (2-sided) \\
\hline Pearson Chi-Square & $1,914^{\mathrm{a}}$ & 4 &, 752 \\
Likelihood Ratio & 1,864 & 4 &, 761 \\
Linear-by-Linear Association &, 639 & 1 &, 424 \\
N of Valid Cases & 360 & & \\
\hline
\end{tabular}

a. 4 cells $(40,0 \%)$ have expected count less than 5 . The minimum expected count is 1,12 . 
*Prevalence of BDD in relation to the gender :

Crosstab

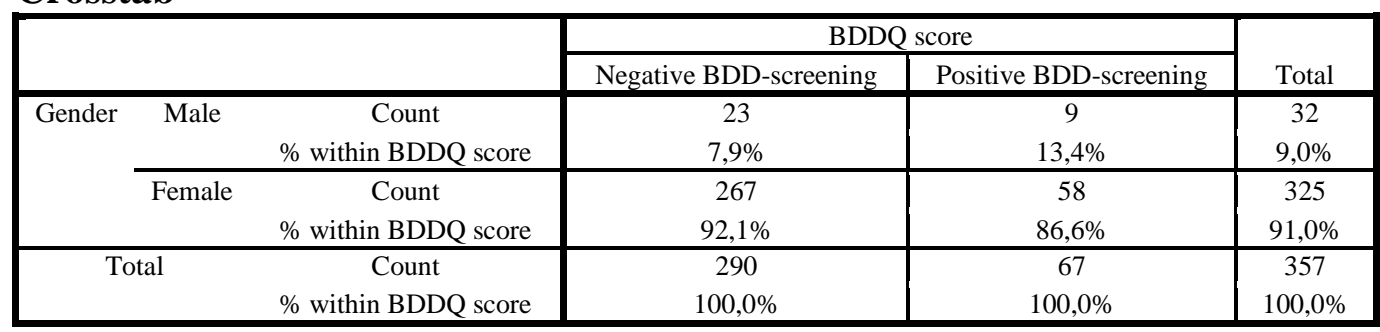

\section{Chi-Square Tests}

\begin{tabular}{|c|c|c|c|c|c|}
\hline & Value & $\mathrm{df}$ & Asymp. Sig. (2-sided) & Exact Sig. (2-sided) & Exact Sig. (1-sided) \\
\hline $\begin{array}{l}\text { Pearson Chi-Square } \\
\text { Continuity Correction } \\
\text { Likelihood Ratio }^{\text {Liknod }} \\
\text { Fisher's Exact Test } \\
\text { Linear-by-Linear Association } \\
\text { N of Valid Cases }\end{array}$ & $\begin{array}{c}2,019^{\mathrm{a}} \\
1,401 \\
1,835 \\
\\
2,013 \\
357\end{array}$ & $\begin{array}{l}1 \\
1 \\
1\end{array}$ & $\begin{array}{l}, 155 \\
, 237 \\
, 176 \\
\\
, 156\end{array}$ & 159, & 120 \\
\hline
\end{tabular}

a. 0 cells $(0,0 \%)$ have expected count less than 5 . The minimum expected count is 6,01 .

b. Computed only for a $2 \times 2$ table

*Prevalence of BDD in relation to the marital status:

\section{Crosstab}

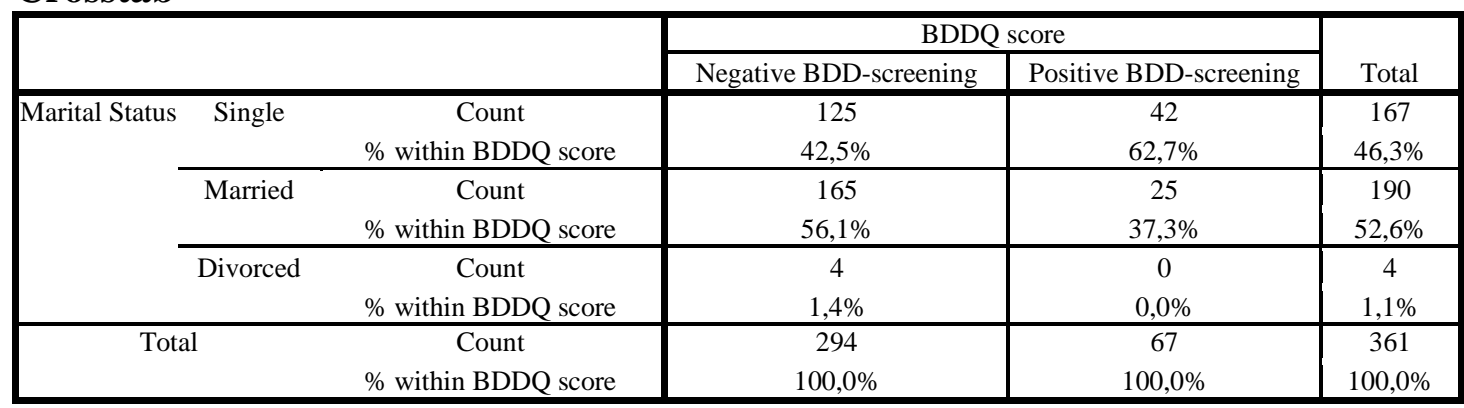

Chi-Square Tests

\begin{tabular}{|c|c|c|c|}
\hline & Value & df & Asymp. Sig. (2-sided) \\
\hline Pearson Chi-Square & $9,378^{\mathrm{a}}$ & 2 &, 009 \\
Likelihood Ratio & 10,066 & 2 &, 007 \\
Linear-by-Linear Association & 9,349 & 1 &, 002 \\
N of Valid Cases & 361 & & \\
\hline
\end{tabular}

a. 2 cells $(33,3 \%)$ have expected count less than 5 . The minimum expected count is, 74 .

*Prevalence of BDD in relation to the occupation:

Crosstab

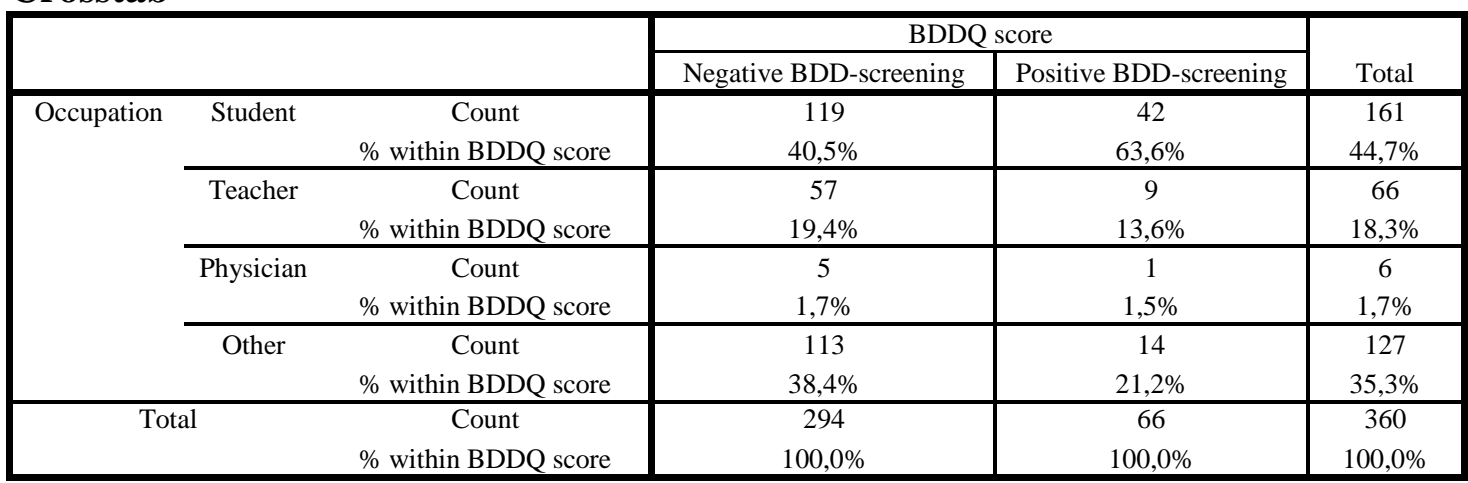




Chi-Square Tests
\begin{tabular}{|c|c|c|c|}
\hline & Value & df & Asymp. Sig. (2-sided) \\
\hline Pearson Chi-Square & $11,981^{\mathrm{a}}$ & 3 &, 007 \\
Likelihood Ratio & 12,075 & 3 &, 007 \\
Linear-by-Linear Association & 9,977 & 1 &, 002 \\
N of Valid Cases & 360 & \multicolumn{3}{|c|}{} \\
\hline
\end{tabular}
a. 2 cells (25,0\%) have expected count less than 5. The minimum expected count is 1,10.

*Prevalence of BDD in relation to the educational level: Crosstab

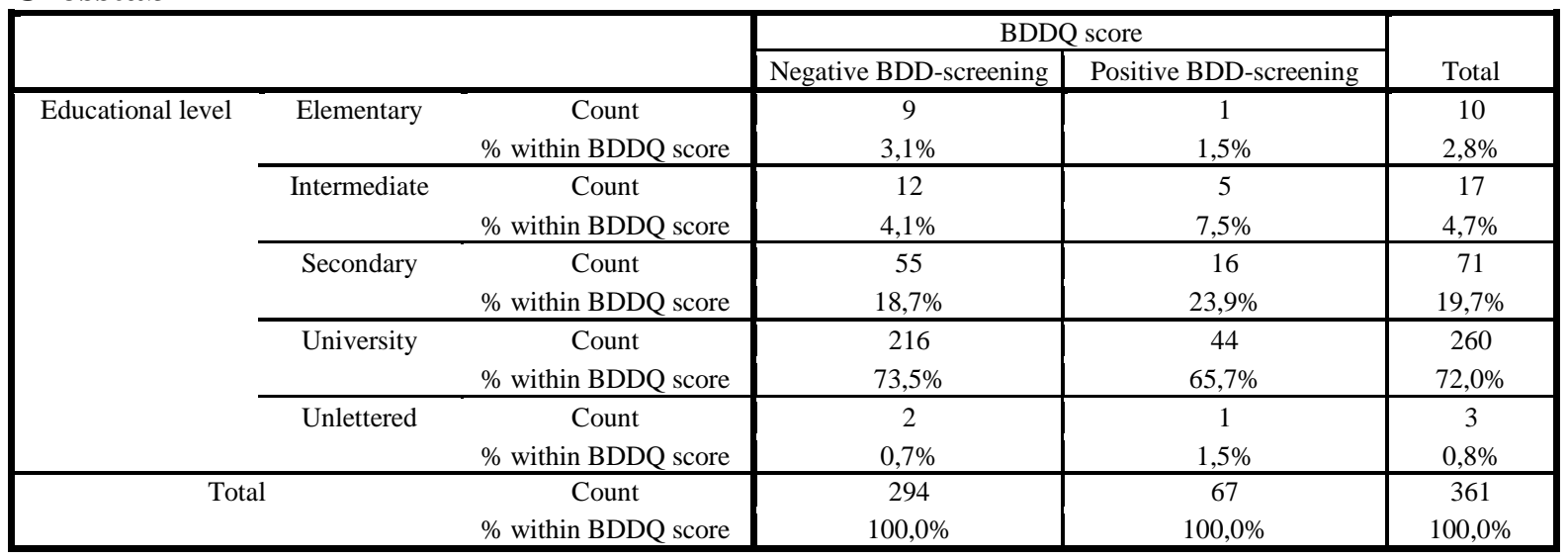

\section{Chi-Square Tests}

\begin{tabular}{|l|c|c|c|}
\hline & Value & df & Asymp. Sig. (2-sided) \\
\hline Pearson Chi-Square & $3,446^{\mathrm{a}}$ & 4 &, 486 \\
Likelihood Ratio & 3,282 & 4 &, 512 \\
Linear-by-Linear Association &, 440 & 1 &, 507 \\
N of Valid Cases & 361 & & \\
\hline
\end{tabular}

Table 3 Areas of concern in the body in eight patients screened positive for body dysmorphic disorder

\begin{tabular}{|c|c|}
\hline Concerns & $\mathrm{n}$ \\
\hline Nose & 5 \\
Body asymmetry & 3 \\
Scars & 3 \\
Pigmentations & 1 \\
Acne and facial & 2 \\
dimples & 0 \\
Wrinkles & \\
& \\
\hline
\end{tabular}

\section{Discussion}

Of the total 363 patients, $176(48.6 \%)$ aged between 15-25. 32 (8.9\%) were male and 326 $(91.1 \%)$ were female. almost all participants were Saudi 331 (91.4\%) and most of them lived in Buradiah city 202 (56,0\%). 161 (44,6) were students and $260(71,8 \%)$ with university level of education. $191(52,8 \%)$ were married and 167 $(46,1)$ were single. The demographic characteristics are detailed in table 1.
Regarding the prevalence of BDD, out of the total 363 patients who participated in this study 294 $(81,4 \%)$ were screened negative for BDD and 67 $(18,6 \%)$ were screened positive for BDD table it seems that BDD significantly decrease with age $(\mathrm{p}=0,001)$ and highly expressed in student $(\mathrm{p}=0,007) .42$ of those who screened positive for BDD aged between 15-25.BDD also appear to be highly expressed in married patients more than those who are single $(\mathrm{p}=0,009)$. furthermore, 9 $(13,4 \%)$ male patients and $58(86,6 \%)$ female patients were screened positive for BDD and this appear to be statistically. None of the BDD report a previous suicidal attempt, however 4 of them report a previous psychiatry visits but not for the BDD as none of them had received the diagnosis of BDD. Most of the BDD patient reported more than one area of concern including: nose, body asymmetry, scars, pigmentations, acne and facial dimples seen in table 4 . 
The current survey showed that $18,6 \%$ of patients likely to undergo Body Dysmorphic Disorder. Thanveer F. Et al. (2016) found that 4,5\% of the studied population were positive BDD screened (4), they also mentioned that prevalence of BDD among US adults was 2,4\% (2008) and among German subjects was 1,8\% (2008). In a small Turkish sample of 200 patients, S. DogrukKacar et al. (April 2014) reported that 6,3\% of the study sample were diagnosed with BDD ${ }^{(5)}$. Previous studies reported BDD proportion range between 63 and $11,9 \%(4,6,7)$ whichis still lower than our results. The proportion of patients with possible BDD was showed significantly decreasing with age $(\mathrm{p}=0,000)$, however it was significantly highly expressed in married patients and among students (respectively $\mathrm{p}=0,009, \mathrm{p}=0,007$ ). As in our survey, results by Katharine A. Philips et al. and Thanveer F. Et al. indicated that BDD usually commence at adolescence $^{(4,8)}$.

As Limitations, this study included only a sample from one region in KSA, and thus our findings may not be representative of the results of BDDQ use among dermatology patients in all Saudi Arabia regions, also the use of translated version in Arabic of the questionnaire that may not be faithful to the original version. However, the use of reliable and valid study tool (BDDQ) would maximize the accuracy and correspond to a strong point for the study.

\section{Conclusion}

Body Dysmorphic Disorder in patients attending dermatology clinic in Qassim region (KSA) is relatively common. Dermatologists should master the measures to identify this health problem in their patients and refer them to mental health specialists.

\section{References}

1. Handbook on Obsessive-Compulsive and Related Disorders edited by Edited by
Katharine A. Phillips M.D., Dan J. Stein M.D. Ph.D.

2. Phillips KA. Body dysmorphic disorder: recognizing and treating imagined ugliness. World Psychiatry. 2004;3(1):12-17.

3. Dermatologic Surgery: Official Publication For American Society For Dermatologic Surgery [et Al.]. 27(5):45762, MAY 2001

4. Thanveer F, Khunger N. Screening for Body Dysmorphic Disorder in a Dermatology Outpatient Setting at a Tertiary Care Centre. Journal of Cutaneous and Aesthetic Surgery. 2016 Jul-Sep;9(3):18891. PubMed PMID: PMC5064684.

5. Dogruk Kacar S, Ozuguz P, Bagcioglu E, Coskun K, Uzel Tas H, Polat S, et al. The frequency of body dysmorphic disorder in dermatology and cosmetic dermatology clinics: a study from Turkey. Clinical and experimental dermatology. 2014;39 (4): 433-8.

6. Phillips KA, Menard W. Suicidality in Body Dysmorphic Disorder: A Prospective Study. The American journal of psychiatry. 2006;163(7):1280-2. PubMed PMID: PMC1899233.

7. Mackley CL. Body dysmorphic disorder. Dermatologic surgery : official publication for American Society for Dermatologic Surgery [et al]. 2005 May;31(5):553-8. PubMed PMID: 15962740. Epub 2005/06/21. eng.

8. Phillips KA, Menard W, Fay C, Weisberg R. Demographic Characteristics, Phenomenology, Comorbidity, and Family History in 200 Individuals With Body Dysmorphic Disorder. Psychosomatics. 2005;46(4): 317-25. PubMed PMID: PMC1351257. 